\title{
燕麦及燕麦糠の養鵎哃料としての価値 \\ Values of Whole Oats and Oats Bran as an \\ Ingredient of Poultry Feeds
}

\author{
日本配合飼料株式会社研究場 \\ Laboratory of Nippon Scientific and Compound Feed Company
}

\section{露 木 寿 (Hisashi Tsuyuki) 田中 庸雄 (Tsuneo Tanaka)}

In America and Europpe oats are used as an ingredient of horse and poultry feeds.

On the other hand, in Japan they are usud as horse feed only. But recently they are adopting as a crop in some regions and it is expected that there will be an increase of oats production. Therefore, nutritive value of oats as an ingredient of poultry feed is demanded and whole oats (heavy oats, $850 \mathrm{gr}$, per sho) and oats bran were used in place of whole wheat in the chick rations of our experiment.

Gain of body weight mortality, feed intake, feed utilization and etc, were observed. Summary.

1) Growth results indicate that whole wheat may be replaced with whole oats or oats bran,

2) There was little difference in mortality at levels of $25 \sim 27 \%$ of oats or oats bran in the rations,

3) The presence of the "Cannibalism-preventing factor" was not confirmed in our 6 week experimental period,

緒言 䜩麦は欧米諸国に於ては馬糧以外に養鶏飼料として相当使用せられ，多きは $30 \%$ も配合された成 舀用配合飼料が市販されている。

幼雛時の多量給与, 特に粗砕燕麦の場合にありては筋胃の圧着, 及び他の消化器の失調を来すといわれて いるが, 成長した鶏にありては, むしろ成長, 羽毛の発育を促進し, 特に啄羽癖, 食血癖, 尻つつき等の所 謂 Cannibalism の防止となるという実験もある。

Kennard \& Chamberlin 等 (1936) の 9 年間の飼育試験及び Wilcke (1940) の圾験によれば 1 ブッセ ル32ポンドの重量の重い燕麦は幼雛用飼料に好適し, 殼の多い軽質の燕麦にありても, 配合飼料の繊維含量 8\%を越えない限り中雛及び成鷄用飼料の原料として適しているという。

然るに本邦に於ては燕麦は従来馬糧としては珍重せらるるも養鵴飼料としては殆えど使用されていない。 その理由は, 栽培が局地的であり, 且つ産額が少く, 従って不廉であるのと, その脱穀技術が困難である等 の為と考えられる。然るに最近, 開拓地及び寒冷地, 並びに冷害地の後作等に之が栽培せらるる向も多く, 将来の増産を期待し得ると思われるので本邦燕麦に就いて本実験を試みた。冎オートミールを製造する場合 に出来る燕麦棣に就いても同様の実験を試みたのでその結果について報告する。

1) 供試品 北海道産全粒燕麦及びオートミール製造の際に生ずる燕麦棣を用いた。 その組成は第 1 表の 如くである。晑燕麦 1 升の重量は $850 \mathrm{~g}$ であった。 
68

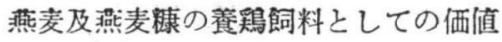

第 14 巻

2 給与飼料の配合率 上記供試品を $1 \mathrm{~mm}$ 篩を 通ずる細粉に粉砕し第 2 表の如く調製した。

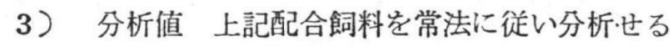
結果は第3 表の如し。

4 供試雊と試験日時

a 第 1 回試験

試験日時 昭和31年 1 月 10 日 2 月 21 日

供試雊 白レグメロードアイランドレッド交 配種 初生雛各区 28 羽

b 第 2 回試験

試験日時 昭和31年 2 月 28 日 4 月 3 日

供試雛 白レグメロードアイランドレッド交配 種 初生雊各区 43 羽

5) 実験方法 1.2 尺 $\times 3$ 尺 $\times 6$ 尺 金網床電熱育雛 箱に各区夫々を収容し, 卯化後60時間頃と覚ぼしき頃 第 3 表

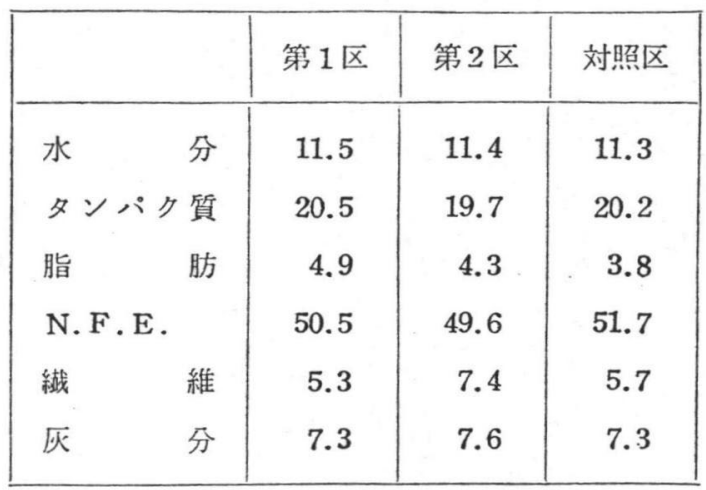

第 4 表 第 1 回試験

\begin{tabular}{|c|c|c|c|c|c|c|}
\hline & 第 & 区 & 第 & 区 & 対 & 区 \\
\hline & 平均個体重 & 増 体 量 & 平均個体重 & 増 体 量 & 平均個体重 & 増 体 量 \\
\hline 飭付前 & 35.3 & & 35.4 & & 36.4 & \\
\hline 1週 & 66.7 & 31.4 & 67.1 & 31.7 & 64.1 & 27.7 \\
\hline 2 週 & 128.0 & 92.7 & 126.8 & 91.4 & 127.5 & 91.1 \\
\hline 3 週 & 215.2 & 179.9 & 207.4 & 172.0 & 207.3 & 170.9 \\
\hline 4 週 & 318.4 & 283.1 & 304.8 & 269.4 & 307.8 & 271.4 \\
\hline 5 週 & 433.0 & 397.7 & 412.9 & 377.5 & 423.7 & 387.3 \\
\hline 6 週 & 567.9 & 532.6 & 534.2 & 498,8 & 557.3 & 520.9 \\
\hline
\end{tabular}


第 3 号

栄 養 学 雑 誌

69

を見計らいV型給慨器にて各供試飼料を不断給与し，残餌は毎日称量して次の餌料に混合給与した。 飲水は自由摂取とし緑飭は給与せず。

6 実験結果

a 体重 毎週午前 10 時個体別に体重を秤量した。

各区の平均体重, 増体重は第 4 , 第 5 表の如し。

第 5 表 第 2 回試験

\begin{tabular}{|c|c|c|c|c|c|c|}
\hline \multirow[b]{3}{*}{ 餌付前 } & & 区 & 第 & 区 & 対 & 区 \\
\hline & 平均個体重 & 増 体 量 & 平均個体重 & 増 体 量 & 平均個体重 & 増 体 量 \\
\hline & 37.9 & & 38.5 & & 38.6 & \\
\hline 1 週 & 59.3 & 21.4 & 61.3 & 22.8 & 64.8 & 26.2 \\
\hline 2 週 & 107.0 & 69.1 & 107.4 & 68.9 & 108.4 & 69.8 \\
\hline 3 週 & 184.4 & 146.5 & 189.6 & 151.1 & 182.4 & 143.8 \\
\hline 4 週 & 286.0 & 248.1 & 297.7 & 259.2 & 282.3 & 243.7 \\
\hline 5 週 & 391.3 & 353.4 & 399.4 & 360.9 & 410.3 & 371.7 \\
\hline
\end{tabular}

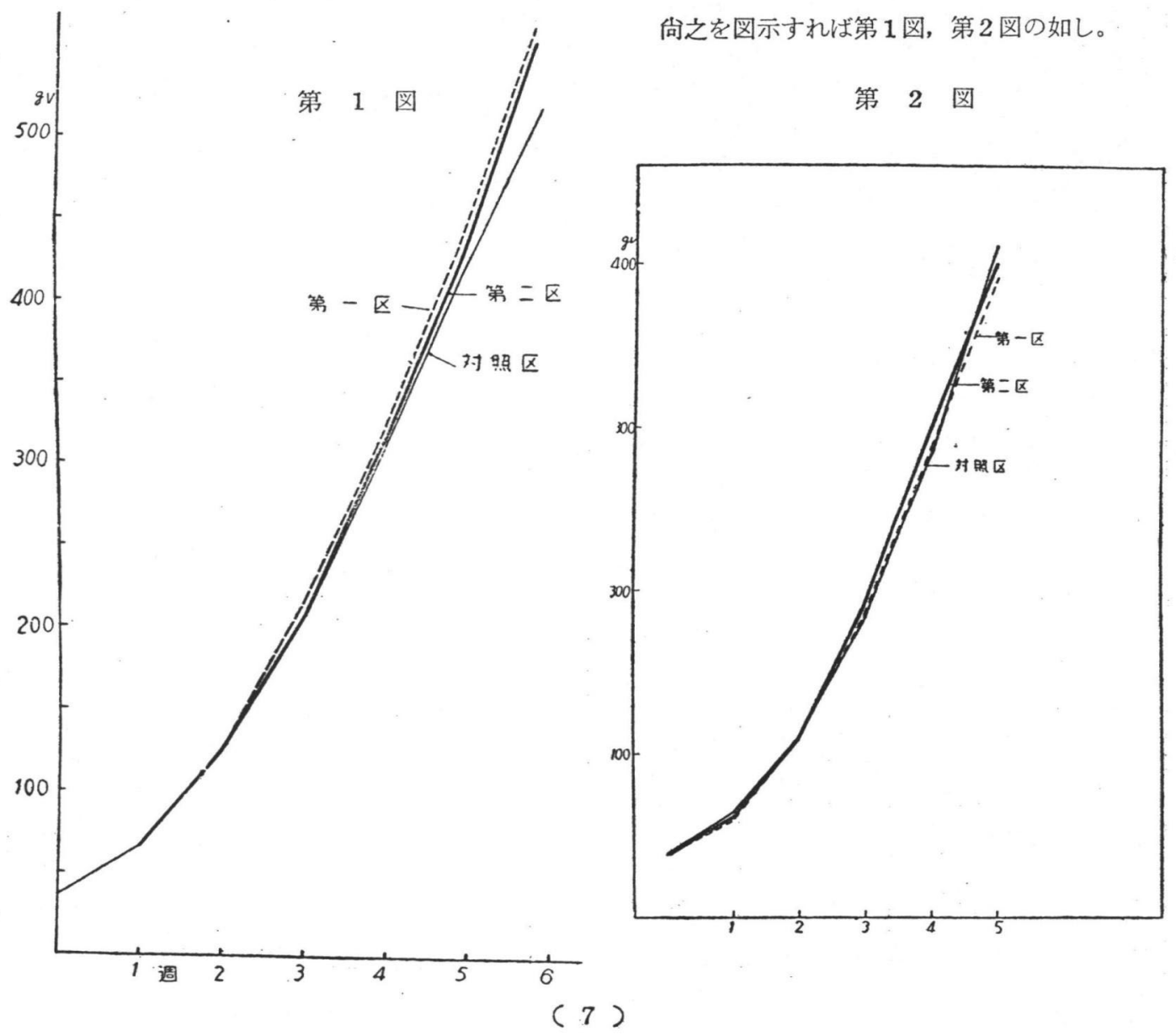


第 6 表

\begin{tabular}{|c|c|c|c|c|}
\hline & & & 第 1 回試験 & 第 2 回試験 \\
\hline 第 & 1 & 区 & 6 & 1 \\
\hline 第 & 2 & 区 & 4 & 2 \\
\hline 対 & 照 & 区 & 5 & 1 \\
\hline
\end{tabular}

第 7 表 第 1 回試験

\begin{tabular}{|rr|r|c|c|}
\hline & & 第 1 区 & 第 2 区 & 対 照 区 \\
\hline 1 & . 週 & 76.6. & 76.6 & 67.9 \\
2 & . 週 & 152.3 & 139.8 & 133.7 \\
3 & . 週 & 210.2 & 233.9 & 207.0 \\
4 & . 週 & 310.9 & 345.7 & 316.5 \\
5 & 週 & 401.6 & 435.0 & 402.5 \\
6 & 週 & 451.8 & 484.3 & 454.3 \\
\hline
\end{tabular}

第 8 表 第 2 回試験

\begin{tabular}{|c|c|c|c|c|}
\hline & & 第 1 区 & 第 2 区 & 対 照 区 \\
\hline 1 & 週 & 45.3 & 49.1 & 43.6 \\
\hline 2 & 週 & 115.0 & 126.8 & 114.8 \\
\hline 3 & 週 & 173.7 & 193.0 & 173.0 \\
\hline 4 & 週 & 265.3 & 306.3 & 263.3 \\
\hline 5 & 週 & 329.0 & 371.1 & 349.3 \\
\hline
\end{tabular}

第 9 表 第 1 回試験

\begin{tabular}{|ll|ll|l|l|}
\hline & & 第 1 区 & 第 2 & 区 & 対 照 区 \\
\hline 1 & 週 & 41.5 & 41.5 & 40.9 \\
2 & 週 & 40.8 & 42.6 & 46.6 \\
3 & 週 & 41.1 & 34.5 & 39.0 \\
4 & 週 & 33.2 & 28.2 & 31.5 \\
5 & 週 & 28.6 & 24.8 & 28.8 \\
6 & 週 & 29.8 & 25.0 & 29.4 \\
\hline
\end{tabular}

b 獘死

試験期間中の整死は第 6 表の如し。

即ち第 1 回試験に於て第 1 週内に第 1 区 6 羽, 第 2 区 4 羽，対照区 5 羽の擎死雛を見だが之は所 謂弱雊であって飼料が原因とは見做されない。

C 採食量

第 10 表 第 2 回試験

\begin{tabular}{|ll|l|l|l|}
\hline & & 第 1 区 & 第 2 区 & 対 照 区 \\
\hline 1 & 週 & 47.2 & 46.4 & 54.1 \\
2 & 週 & 41.5 & 36.4 & 37.1 \\
3 & 週 & 44.6 & 41.0 & 42.7 \\
4 & 週 & 37.7 & 35.3 & 36.3 \\
5 & 週 & 32.0 & 27.4 & 36.7 \\
\hline
\end{tabular}

第 3 図

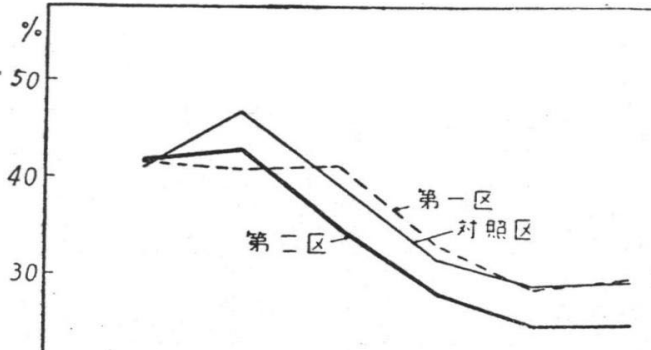

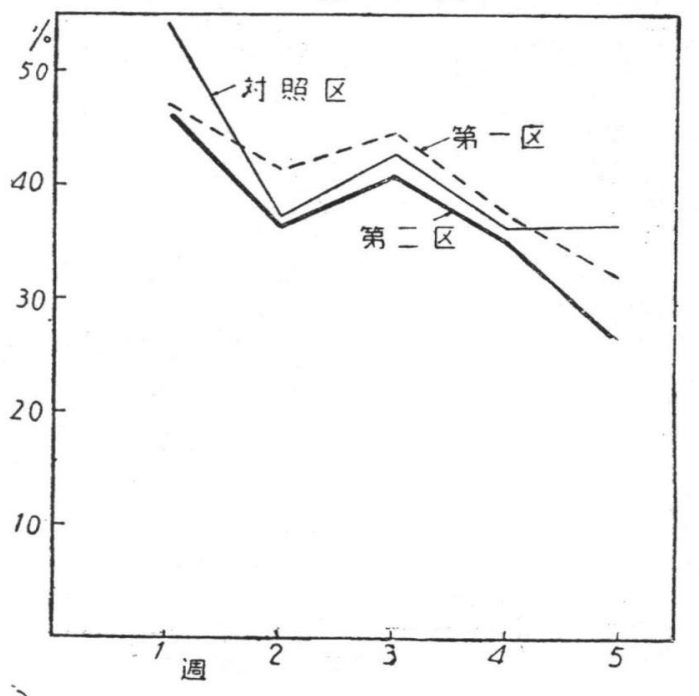


第 3 号

試験期間中の総採食量及び平均採食量は第 7 表の如し。

d 飼料利用率

平均増体量/平均採食量は第 9,10 表の如し。

之を図示すれば第 3 図，第4図の如し。

e. 其の他の観察 試験期間中の採食状態, 健康状態, 䔬便等は何等異状を認めなかった。Cannibalism に就いては対照区に於ても発現しなかったので, 特に燕麦にその効果があるとは本実験に関する限り認め難 い。

\section{総 括}

1)成長結果から見て, 1 升 850 グラムの燕麦（比較的重いoast） は小麦の代用として或る程度利用出来 るものと考えられる。

2) oats 又は oats 棣を 25〜27\% 程度では整死率は殆えど差がなかった。第 1 週中に各区数羽のひなが 獘れたが,これは生来弱雛として考元て差支えない。2週以後は整れなかっだ。

3)キャニバリズムを予防する因子が oats 殻の中に存在するとの実証は, 本実験期間に於ては断定し難 い。

以上を要約して oats 全粒粉砕物又は，oats ヌカは初生びな用飼料の小麦の代用として 相当の価値あるも のと思われる。

終りに，本実験を行うに当り種々有益なる御助言と御指導を賜りたる当研究場長西川哲三郎博士に深謝の 意を表し，動物飼育を担当された芳賀，藤田君，分析担当の吉田君に感謝する。

\section{交 献}

Wilcke, H.L. : Oats Rank First for Poultry Feed, Farm Science Reporter January, 1940.

Kennard. D. C. and Chamberlin, V. D. : Oats for Chickens. Ohio Bi-monthly Bul., 21, 9597, 1936.

Spector, H. and Elvehjem C. A. : Wisconsin Agricultural Expt, Stat. Annual Report, Bul., 456, 1940.

Lampman, C.E. and Thompson, J. N. : 49th Annual Report, University of Idaho, 1942. Sanford, Paul and Wilcke : Poultry Sci., 23. 4, 1944.

Sehaible. P. J., Davidson, J. A., et Band Selma L. : Poul. Sci., 26. 651. 1947.

Davis, Frank et Briggs, G. M. : J. Nutri., 34, Sept., 1947

Bearse, Berg. McClary et Miller : Pout. Sci., 28, 756, 1949.

Insko, W. M., Jr., and Culton. T. G. : Poultry Sci,, 28, 769, 1949

Encyclopédie-Roret, : Mannel pratiqué de Léleveur de Poules. Par H. L. Alph. Blanchon Sutlic: A dictionary of poultry, p. 189, 190.

Morrison : Feeds and Feeding.

Feedstuffs : 28, 20, 1956.

鈴木幸三 : 養鷄飼料新知識

岩田久敬 : 飼料学

斎藤道雄：飼料学上巻 
海塩義男：家音飼養.

中川一郎, 二国二郎, 吉川春寿 : 栄養学.

波多野正：家禽飼養学

露木 寿：音産の研究, 10,1 .

\section{抄 録}

\section{老人の栄養状態}

Nutritional Status of the Aging Harold

D. Chope and Lester Breslow; Ameri.

Jour. of Public Health., 46, 61, 1956.

本報告は60才以上 90 才までの男女577名（男280, 女297）について1948年から1954年に至る7年間に互 って行われた。米国の多数の機関の共同の調査研究 の一部で, 主として老人の死亡率と肥満, 高血圧, 血液中コレステロール量および各種ビタミン量との 関係について述べられている。

7年間の死亡者数は 88名で死亡率は $15.3 \%$, 男子 $22.5 \%$ ，女子 $8.4 \%$ あるあ。死因の第一は心臓およ び循環器の疾患で総数の $54 \%$ を占めている。

高血圧。最高血圧 $180 \mathrm{~mm}$ 以上のものは最高血圧 $140 \mathrm{~mm}$ 以下のものに比して男子は4倍，女子は 1.5 倍の死亡率を示した。

肥満。体重が平均よりも16\%あるいはそれ以上の 者は85名 $(18.8 \%)$ あり, 過剩体重と心臓, 循環器 系疾患による死亡との間には明らかに相関関係が認 められ，平均体重の人の約 2 倍の死亡率を示してい る。

血液中コレステロール。血清中のコレステロール は男子 $241 \pm 8 \mathrm{mg}$ ，女子 $270 \pm 8 \mathrm{mg} / 100 \mathrm{ml}$. で著者 等の成績では高コレステロール血と心臟, 循環器, 腎臓系疾患による死亡との間には関係が見られなか った。そして70才以上の者については, 高コレステ ロール血の方が却って低コレステロール血の者より 死亡率が低いという数字になった。

各種ビタミン。血液中のビタミン量と死亡率との 関係を見ると，ビタミンA，ナイフシンおよびビタ ミンCについては何れもそれらの量が低い方が死亡
率が高いという結果になった。

以上の外, へモグロビン, 血糖, 血液中のクレア チニン, カロリー摂取量, その他蛋白質, 糖質, 脂 肪, カルシウムおよび鉄等の摂取量と死亡率との関 係を見たがそれらの因子との間には有意の関係は認 められなかった。

歯牙は経済的に恵まれた階級の者にその残存が多 く，低い階級の者には残存数が少なかった。これは 栄養が良くないのと，歯に対する注意が不十分なた めであろう。血液中のビタミンC 量と歯牙の数につ いて見るとビタミンCの多い程，傊数が少い。こ れからするとビタミンCを十分摂って血液中の量を 維持することは，歯の保存ばかりでなく，歯龈炎の 予防にも役立ち, 口腔衛生上必要であると思われ る。

(速水)

\section{加工魚肉アミノ酸の評価}

Evaluation of Amino Acids in Fish

Processed by Various Methods.

B. E. Proctor, N. L. Lahiry; Food

Research 20, 91 (1956).

Shad (Alosa sapidissima) \& Haddock ( $M e$ lanogrammus aeglefinus) 蒸煮肉の切身をアス コルピン酸の0.05\%に漬けた後乾燥したもの, その まま乾燥したもの, 冷凍したものを処理して鑵詰に したもの, 又新鮮魚をフレーク鑵詰にしたものにつ いて Leuconosoc mesenteroides P-60 による微 生物法によって各試料加工魚肉蛋白質の必須了ミノ 酸を測定し, 新鮮物の値と比較して, この様な加工 によっては殆んど变化のない事を見出した。

(馬場) 